\title{
GIRK channel activity of Hungarian mushrooms: From screening to biologically active metabolites
}

\author{
Attila Ványolós ${ }^{\mathrm{a}, *, 1}$, Péter Orvos ${ }^{\mathrm{b}, \mathrm{c}, 1}$, Bayar Chuluunbaatar ${ }^{\mathrm{a}}$, László Tálosi ${ }^{\mathrm{a}}$, Judit Hohmann ${ }^{\mathrm{a}, \mathrm{d}}$ \\ ${ }^{a}$ Department of Pharmacognosy, Interdisciplinary Excellence Centre, University of Szeged, Eötvös u. 6, H-6720 Szeged, Hungary \\ ${ }^{\mathrm{b}}$ Department of Ophthalmology, University of Szeged, Korányi fasor 10-11, H-6720 Szeged, Hungary \\ ${ }^{\mathrm{c}}$ Department of Pharmacology and Pharmacotherapy, University of Szeged, Dóm tér 12, H-6720 Szeged, Hungary \\ d Interdisciplinary Centre for Natural Products, University of Szeged, Eötvös u. 6, H-6720 Szeged, Hungary
}

\section{A R T I C L E I N F O}

\section{Keywords:}

Mushroom

GIRK

hERG

Ion channel

Triterpene

Hypholoma lateritium

\begin{abstract}
A B S T R A C T
In the current study effects of fungal extracts on the G-protein-activated inwardly rectifying potassium channel (GIRK1/4) were screened using the automated patch-clamp method. 40 organic ( $n$-hexane, chloroform, and $50 \%$ methanol) and aqueous extracts were prepared from 10 mushroom species native to Hungary. Among the examined fungal fractions of different polarities some $n$-hexane and chloroform extracts exerted considerable ion channel activity. One of the most active fungal species, Hypholoma lateritium was selected for further detailed examination to determine the compounds responsible for the observed pharmacological property. Evaluation of the ion channel activity of mushroom metabolites 1-10 revealed that lanosta-7,9(11)-diene-12 $\beta, 21 \alpha$-epoxy$2 \alpha, 3 \beta, 24 \beta, 25$-tetraol (5) demonstrates remarkable blocking activity on GIRK current (IC ${ }_{50} 395.1 \pm 31.8 \mathrm{nM}$ ). Investigation of the selectivity of the GIRK inhibitory effect proved that lanosta-7,9(11)-diene-12 $\beta, 21 \alpha$-epoxy$2 \alpha, 3 \beta, 24 \beta, 25$-tetraol (5) has only weak inhibitory activity on hERG channel (7.9 $\pm 2.8 \%$ at $100 \mu \mathrm{M})$, exerting more than three orders of magnitude lower blocking activity on hERG channel than on GIRK channel.
\end{abstract}

\section{Introduction}

Atrial fibrillation (AF) is a supraventricular tachyarrhythmia with uncoordinated atrial activation and, accordingly, ineffective atrial contraction. AF is the most common cardiac rhythm disturbance in adults and the prevalence of this arrhythmia increases sharply with advancing age. AF is potentially associated with life-threatening cardiovascular conditions such as thromboembolism, stroke and heart failure, consequently results in significant morbidity and mortality [1].

Even though the underlying mechanisms of $\mathrm{AF}$ is not yet entirely understood, the cardiac acetylcholine-activated potassium ion channel $\left(\mathrm{I}_{\mathrm{KACh}}\right)$ is considered a novel and attractive target for drug therapy in the treatment of AF [2]. This ion channel is member of the G-proteincoupled inwardly rectifying potassium channel (GIRK) superfamily and is composed of GIRK1/4 (Kir3.1 and Kir3.4) subunits [3]. It has been described that GIRK1/4 is constitutively active in myocytes from patients with chronic AF or from dog model of atrial tachycardia, and, furthermore, these studies have demonstrated spontaneous openings of these channels in myocytes from chronic AF patients [2,4,5]. Potent selective inhibitors of GIRK, tertiapin and NIP-151 terminated AF, and favorably prolonged the atrial effective refractory period in canine AF model [6,7]. Taking all these findings together, constitutively active GIRK channels in the atrium elevate proarrhythmic risk by causing dispersion of atrial repolarization and refractoriness, therefore, a selective GIRK blocker without affecting ventricular repolarization is effective and might be useful for the treatment of patients with AF.

A selective atrial target is extremely important. GIRK1 and GIRK4 subunits are abundant in atrium, but expressed in very small amounts in ventricle $[8,9]$. However, many of drugs exert their arrhythmogenic side effects through the ion channel encoded by the human ether-a-gogo-related gene (hERG, Kv11.1), expressed in cardiac ventricular myocytes, which has shown to be extremely promiscuous in its interactions with a wide range of structurally unrelated molecules such as psychiatric, antimicrobial, antihistamine, and even antiarrhythmic drugs $[1,10]$. hERG represents the $\alpha$-subunit of the ion channel responsible for rapid delayed rectifier potassium current $\left(\mathrm{I}_{\mathrm{Kr}}\right)[11,12]$. The $\mathrm{I}_{\mathrm{Kr}}$ current plays a fundamental role in the phase 3 of repolarization of the action potential; therefore, inhibition of hERG channel delays cardiac action potential repolarization, which lengthens the action potential duration (APD). Prolongation of ventricular action potential

\footnotetext{
* Corresponding author.

E-mail address: vanyolosa@pharmacognosy.hu (A. Ványolós).

${ }^{1}$ These authors contributed equally to this study.
} 


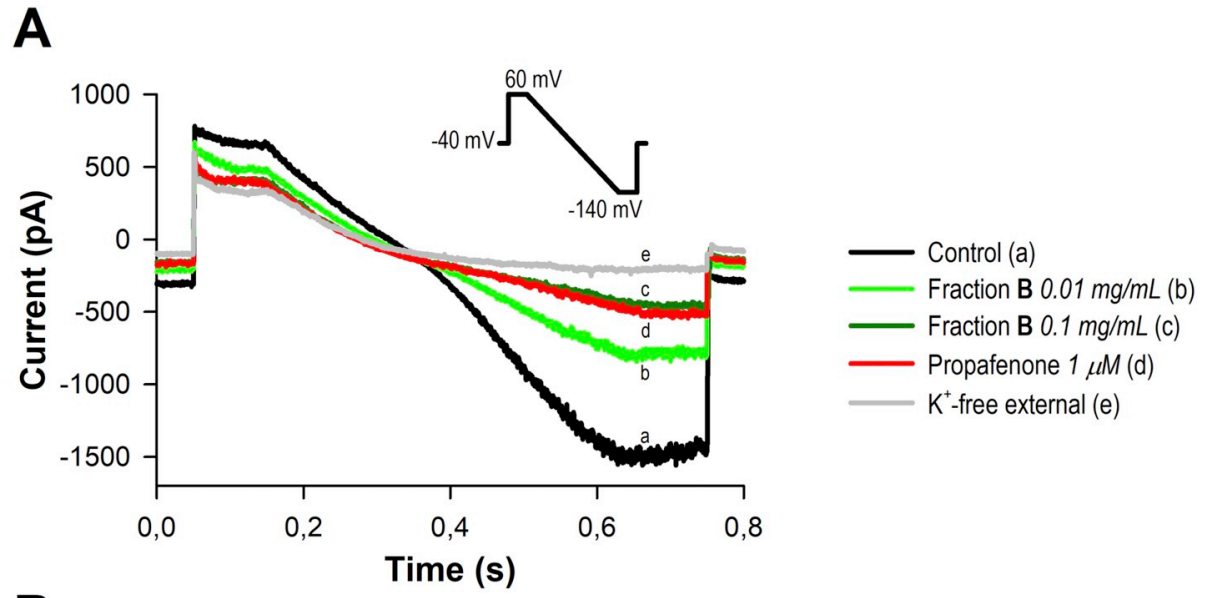

Fig. 1. Blocking effects of fraction B of Hypholoma lateritium on GIRK current. Panel A shows typical current curves which were recorded during application of fraction B of $H$. lateritium at $0.01 \mathrm{mg} / \mathrm{mL}$ and $0.1 \mathrm{mg} / \mathrm{mL}$ concentrations. Inset shows the applied GIRK voltage protocol. Time course of calculated inward currents from the $-140 \mathrm{mV}$ segment of the current sweeps is presented on panel $\mathrm{B}$.

B

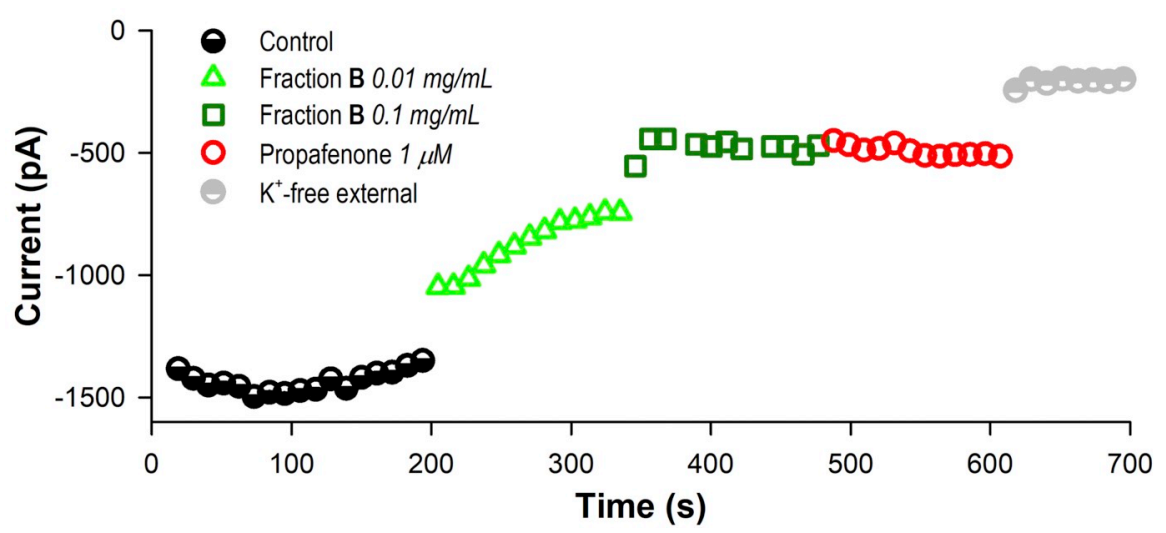

Table 1

Information on fungal species collected.

\begin{tabular}{|c|c|c|c|}
\hline Family & Species & English name & Habitat \\
\hline Entolomataceae & Rhodocybe popinalis (Fr.) Singer & Not known & Mixed woodland \\
\hline Fomitopsidaceae & Laetiporus sulphureus (Bull.) Murrill & Chicken-of-the-woods & Mixed woodland \\
\hline Marasmiaceae & Megacollybia platyphylla (Pers.) Kotl. \& Pouzar & Whitelaced shank & Mixed woodland \\
\hline \multirow[t]{2}{*}{ Omphalotaceae } & Gymnopus dryophilus (Bull.) Murrill & Russet toughshanks & Mixed woodland \\
\hline & Gymnopus fusipes (Bull.) Gray & Spindleshank & Quercus sp. (parasitic) \\
\hline \multirow[t]{3}{*}{ Strophariaceae } & Hebeloma sacchariolens Quél. & Sweet poisonpie & Mixed woodland \\
\hline & Hypholoma fasciculare (Huds.) P. Kumm. & Sulfur tuft & Mixed woodland \\
\hline & Hypholoma lateritium (Schaeff.) P. Kumm. & Brick tuft & Mixed woodland \\
\hline \multirow[t]{2}{*}{ Tricholomataceae } & Tricholoma populinum J.E. Lange & Cottonwood mushroom & Populus sp. (mycorrhizal) \\
\hline & Tricholomopsis rutilans (Schaeff.) Singer & Plums and custard & Pinus sp. (saprobic) \\
\hline
\end{tabular}

duration might be associated with an increased risk of the polymorphic ventricular tachycardia Torsades de Pointes, which can degenerate into ventricular fibrillation and sudden cardiac death [13-15]. In the past, several drugs have been withdrawn from major markets because of their proarrhythmic effect. At present, to avoid severe cardiotoxicity, every new compound must go through preclinical safety testing determined by the U. S. Food and Drug Administration, the European Medicines Agency and other regulatory entities [16].

The popular term mushroom is applied for macrofungi with distinctive fruiting bodies observable to the naked eye. The number of different mushroom species is estimated to be 140,000 , of which only $10 \%$ are known to science. They have long been recognized for their therapeutic values, particularly in traditional medicines of Far-Eastern countries. Mushrooms are valuable sources of biologically active compounds possessing antibacterial, anticancer and immunmodulatory properties [17,18]. Extended investigation of active substances originated from mushrooms in different screening systems may result in further discoveries of valuable new compounds.

In the present study, the effects of basidiomycetes mushroom extracts on the G-protein-activated inwardly rectifying potassium channel (GIRK1/4) were investigated using the automated patch-clamp method. For this purpose organic and aqueous extracts were prepared from 10 different mushrooms native to Hungary. The extracts of different polarities were investigated in the cell-based GIRK channel inhibitory assay on HEK-GIRK cell line. One of the most active species was selected for further detailed chemical examination to determine its biologically active metabolites. The GIRK channel modulatory activities of the isolated compounds were also evaluated, with the aim of discovering new promising blockers of the GIRK1/4 channel. In addition, the most potent blocker of GIRK proteins was further tested for its hERG-related cardiotoxicity with automated patch-clamp technology on HEK-hERG cell line. 
Table 2

Yields and blocking effects of mushroom extracts at $0.01 \mathrm{mg} / \mathrm{mL}$ and $0.1 \mathrm{mg} / \mathrm{mL}$ concentrations on GIRK ion channels $(n=2-3)$.

\begin{tabular}{|c|c|c|c|c|c|c|}
\hline \multirow[t]{2}{*}{ Species } & \multirow[t]{2}{*}{ Solvent } & \multirow[t]{2}{*}{ Yield $(w /$ w\%) } & \multirow{2}{*}{$\begin{array}{l}\text { Inhibition } \% \\
0.01 \mathrm{mg} / \mathrm{mL}\end{array}$} & \multicolumn{2}{|l|}{ SEM } & \multirow[t]{2}{*}{$0.1 \mathrm{mg} / \mathrm{mL}$} \\
\hline & & & & $0.1 \mathrm{mg} / \mathrm{mL}$ & $0.01 \mathrm{mg} / \mathrm{mL}$ & \\
\hline \multirow[t]{4}{*}{ Gymnopus dryophilus } & A & 1.1 & 28 & 72 & 0 & 3 \\
\hline & B & 0.9 & 35 & 80 & 5 & 4 \\
\hline & $\mathrm{C}$ & 7.5 & 10 & 15 & 1 & 2 \\
\hline & $\mathrm{D}$ & 5.2 & 10 & 20 & 5 & 4 \\
\hline \multirow[t]{4}{*}{ Gymnopus fusipes } & A & 2.8 & 29 & 74 & 4 & 8 \\
\hline & B & 1.3 & 30 & 76 & 6 & 0 \\
\hline & $\mathrm{C}$ & 18.3 & 6 & 11 & 1 & 1 \\
\hline & $\mathrm{D}$ & 4.1 & 21 & 30 & 1 & 1 \\
\hline \multirow[t]{4}{*}{ Hebeloma sacchariolens } & A & 1.7 & 33 & 67 & 4 & 5 \\
\hline & B & 1.6 & 37 & 74 & 2 & 1 \\
\hline & $\mathrm{C}$ & 8.2 & 6 & 28 & 3 & 2 \\
\hline & $\mathrm{D}$ & 1.6 & 20 & 37 & 6 & 3 \\
\hline \multirow[t]{4}{*}{ Hypholoma fasciculare } & A & 1.6 & 23 & 53 & 1 & 4 \\
\hline & B & 3.4 & 25 & 60 & 6 & 9 \\
\hline & $\mathrm{C}$ & 7.2 & 16 & 35 & 6 & 3 \\
\hline & $\mathrm{D}$ & 4.0 & 12 & 20 & 4 & 6 \\
\hline \multirow[t]{4}{*}{ Hypholoma lateritium } & A & 2.2 & 33 & 69 & 3 & 1 \\
\hline & B & 1.0 & 53 & 79 & 2 & 1 \\
\hline & $\mathrm{C}$ & 16.4 & 25 & 46 & 0 & 2 \\
\hline & $\mathrm{D}$ & 3.9 & 8 & 14 & 6 & 3 \\
\hline \multirow[t]{4}{*}{ Laetiporus sulphureus } & A & 1.3 & 34 & 74 & 6 & 8 \\
\hline & B & 0.7 & 28 & 68 & 6 & 13 \\
\hline & $\mathrm{C}$ & 5.8 & 25 & 43 & 6 & 11 \\
\hline & $\mathrm{D}$ & 3.6 & 11 & 24 & 1 & 7 \\
\hline \multirow[t]{4}{*}{ Megacollybia platyphylla } & A & 0.9 & 39 & 61 & 3 & 15 \\
\hline & B & 0.5 & 29 & 68 & 6 & 3 \\
\hline & $\mathrm{C}$ & 13.0 & 11 & 11 & 4 & 6 \\
\hline & $\mathrm{D}$ & 6.2 & 8 & 20 & 0 & 6 \\
\hline \multirow[t]{4}{*}{ Rhodocybe popinalis } & A & 1.4 & 19 & 55 & 3 & 3 \\
\hline & B & 0.8 & 10 & 23 & 3 & 5 \\
\hline & $\mathrm{C}$ & 8.8 & 12 & 16 & 1 & 2 \\
\hline & $\mathrm{D}$ & 6.2 & 7 & 16 & 1 & 0 \\
\hline \multirow[t]{4}{*}{ Tricholoma populinum } & A & 6.0 & 5 & 25 & 0 & 4 \\
\hline & B & 1.7 & 41 & 90 & 2 & 1 \\
\hline & $\mathrm{C}$ & 15.0 & 9 & 17 & 1 & 16 \\
\hline & $\mathrm{D}$ & 4.6 & 17 & 20 & 3 & 12 \\
\hline \multirow[t]{4}{*}{ Tricholomopsis rutilans } & A & 1.3 & 16 & 52 & 4 & 3 \\
\hline & B & 2.7 & 37 & 65 & 4 & 12 \\
\hline & $\mathrm{C}$ & 11.5 & 15 & 31 & 8 & 11 \\
\hline & $\mathrm{D}$ & 1.3 & 12 & 17 & 0 & 3 \\
\hline
\end{tabular}

\section{Materials and methods}

\subsection{Samples}

Mushroom samples were collected in Hungary in 2012 by A. Ványolós and members of Mushroom Society of Miskolc and of Mushroom Society of Zemplén (Hungary). The collected species were identified by J. Béres (Mushroom Society of Miskolc), J. Kőszeginé Tóth (Mushroom Society of Zemplén) and A. Ványolós. Representative voucher specimens (No. IC 1-10) have been deposited in the Department of Pharmacognosy, University of Szeged. The samples were stored at $-20^{\circ} \mathrm{C}$ until processing.

\subsection{Sample preparation}

The sporocarps of collected mushrooms were freeze-dried and ground. Each freeze-dried sample $(10 \mathrm{~g})$ was extracted with $3 \times 100 \mathrm{~mL}$ methanol by ultrasonication for $3 \times 15$. After filtration, the solutions were evaporated under reduced pressure. The residues were dissolved in $50 \mathrm{~mL}$ of $50 \%$ aqueous $\mathrm{MeOH}$ and were subjected to solvent-solvent partition between $n$-hexane $\left(4 \times 25 \mathrm{~mL}\right.$ ) (extract A) and $\mathrm{CHCl}_{3}$ $(4 \times 25 \mathrm{~mL})$ (extract B) and the residue gave extract C. After extraction with $\mathrm{MeOH}$, the residual mushroom materials were dried and extracted with $50 \mathrm{~mL}$ of boiling water for $15 \mathrm{~min}$. The filtered extracts were freeze-dried, providing extract D.
Isolation, structure determination and characterization of compounds 1-10 are described elsewhere [19].

\subsection{Automated planar patch-clamp measurements}

GIRK and hERG ion currents were measured using planar patchclamp technology in the whole-cell configuration with a four channel medium throughput fully automated patch-clamp system (Patchliner, Nanion Technologies GmbH, Munich, Germany; [20]. The pipetting protocols were controlled by PatchControlHT 1.09.30 software (Nanion Technologies GmbH., Munich, Germany). Data acquisition and online analysis were performed with an EPC-10 Quadro patch-clamp amplifier (HEKA Elektronik Dr. Schulze GmbH, Lambrecht/Pfalz, Germany), using PatchMaster 2.65 software (HEKA Elektronik Dr. Schulze GmbH, Lambrecht/Pfalz, Germany). Currents were low-pass filtered at $2.9 \mathrm{kHz}$ using the internal Bessel filter of the amplifier and digitized at $10 \mathrm{kHz}$.

Automated patch-clamp experiments were carried out at room temperature on suspension of stable transfected cell lines. Suspension of cells for measurements was derived from running cell culture. Cells were maintained in incubator at $37^{\circ} \mathrm{C}$, in $5 \% \mathrm{CO}_{2}$. Before experiments, cells were washed twice with PBS (Thermo Fisher Scientific Inc., Waltham, USA) and then detached with trypsin-EDTA (PAN-Biotech $\mathrm{GmbH}$, Aidenbach, Germany) for 1-3 min. Trypsin was blocked with serum-containing media. The cell suspension was next centrifuged ( $2 \mathrm{~min}, 100 \mathrm{~g}$ ), resuspended in serum-free media at a final density of 


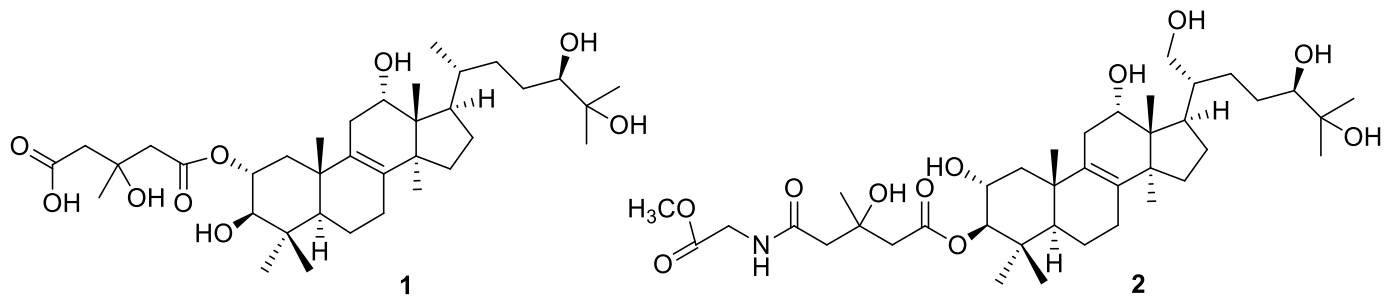

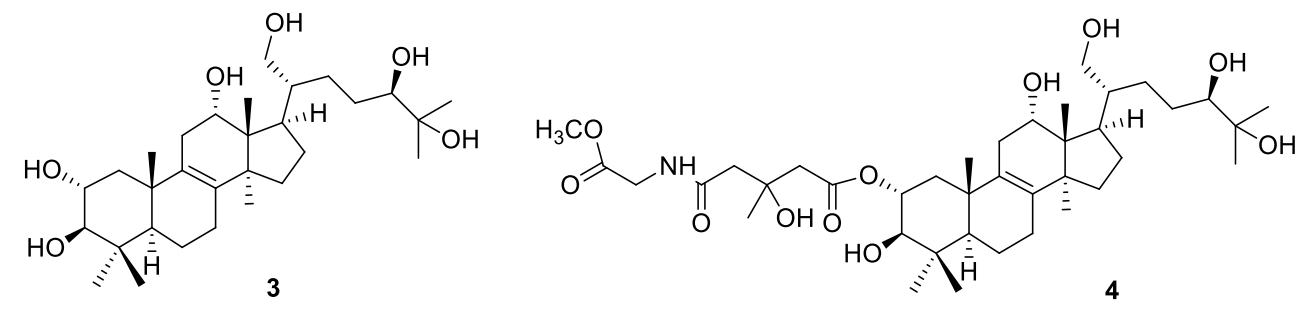<smiles>CC(C)C(C)/C=C/[C@H](C)C(C)/C=C/[C@@H](C)[C@]1(C)CC[C@H]2C3=CC(=O)OC3(C)CC[C@]21C</smiles>

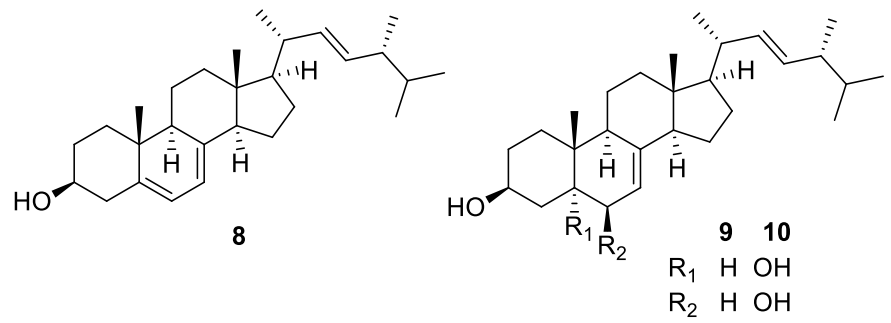

Fig. 2. Triterpenes $(\mathbf{1}-\mathbf{1 0})$ from Hypholoma lateritium.

Table 3

GIRK channel inhibitory activity of isolated compounds of Hypholoma lateritium at $1 \mu \mathrm{M}$ and $10 \mu \mathrm{M}$ concentrations $(n=2-3)$.

\begin{tabular}{llllll}
\hline \multirow{2}{*}{ Compound } & \multicolumn{2}{l}{ inhibition $\%$} & & \multicolumn{2}{l}{ SEM } \\
\cline { 2 - 3 } \cline { 5 - 6 } & $1 \mu \mathrm{M}$ & $10 \mu \mathrm{M}$ & & $1 \mu \mathrm{M}$ & $10 \mu \mathrm{M}$ \\
\hline $\mathbf{1}$ & 13 & 23 & 2 & 8 \\
$\mathbf{2}$ & 11 & 23 & 2 & 3 \\
$\mathbf{3}$ & 10 & 10 & 4 & 7 \\
$\mathbf{4}$ & 10 & 27 & 1 & 2 \\
$\mathbf{5}$ & 27 & 60 & 5 & 11 \\
$\mathbf{6}$ & 11 & 23 & 3 & 1 \\
$\mathbf{7}$ & 14 & 24 & 1 & 5 \\
$\mathbf{8}$ & 10 & 19 & 1 & 6 \\
$\mathbf{9}$ & 8 & 16 & 1 & 6 \\
$\mathbf{1 0}$ & 7 & 13 & 1 & \\
\hline
\end{tabular}

$1 \times 10^{6}-5 \times 10^{6}$ cells $/ \mathrm{mL}$, and kept in the cell hotel of the Patchliner. Cells were recovered after $15-30 \mathrm{~min}$ and remained suitable for automated patch-clamp recordings for up to $4 \mathrm{~h}$.

Stock of extra- and intracellular solutions were made for automated patch-clamp recordings. Chemicals were purchased from Sigma-Aldrich Corporation (St. Louis, USA). All solutions were sterile filtered. Aliquots were stored at $-20{ }^{\circ} \mathrm{C}$ and warmed up to room temperature before use.

Effects of fungal extracts and compounds isolated from Hypholoma lateritium were tested. A stock solution of test material was prepared in each case. The concentrations of the examined substances in the stock solutions were $50 \mathrm{mg}$ of dried material/mL for the mushrooms extract and $10 \mathrm{mM}$ for compounds 1-10. The solubilizing agent was dimethyl sulphoxide (DMSO, Sigma-Aldrich Corporation, St. Louis, USA) in all cases. Aliquots were stored at $-20^{\circ} \mathrm{C}$. Before experiments, stock solutions were further diluted with high $\mathrm{K}^{+}$external solution (GIRK assay) or external solution (hERG assay) to give appropriate concentrations for the measurements. The final DMSO concentrations in the tested samples were $1 \%$ or less.

\subsubsection{GIRK channel inhibitory assay}

Experiments were carried out on HEK-293 (human embryonic kidney) cells stably expressing the GIRK1/4 (Kir3.1/3.4) $\mathrm{K}^{+}$channels by adapting a method described earlier [21]. Cell line originated from UCL Business Plc. (London, Great Britain). Cells were maintained in DMEM (Thermo Fisher Scientific Inc., Waltham, USA) medium supplemented with 10\% FBS (PAN-Biotech GmbH, Aidenbach, Germany) and $182 \mu \mathrm{g} / \mathrm{mL}$ zeocin (Thermo Fisher Scientific Inc., Waltham, USA).

The following solutions were used during patch-clamp recordings (compositions in $\mathrm{mM}$ ): external solution: $\mathrm{NaCl} \mathrm{140,} \mathrm{KCl} \mathrm{4,} \mathrm{glucose-}$ monohydrate 5, $\mathrm{MgCl}_{2} 1, \mathrm{CaCl}_{2} 3$ and HEPES 10 (pH 7.4, NaOH); high $\mathrm{K}^{+}$external solution: $\mathrm{NaCl} 135, \mathrm{KCl} 25, \mathrm{MgCl}_{2} 1, \mathrm{CaCl}_{2} 3$ and HEPES 10 (pH 7.4, NaOH); $\mathrm{K}^{+}$-free external solution: $\mathrm{NaCl} 160, \mathrm{MgCl}_{2} 1, \mathrm{CaCl}_{2} 3$ and HEPES 10 (pH 7.4, NaOH); internal solution: K-gluconate 40, NaCl 20, KF 60, EGTA 20 and HEPES 10 (pH 7.2, KOH), supplemented with $0.9 \mathrm{mM}$ GTP $\gamma \mathrm{S}$ before the experiments to induce channel activation.

The voltage protocol for GIRK ion channel assay (see inset on Panel 


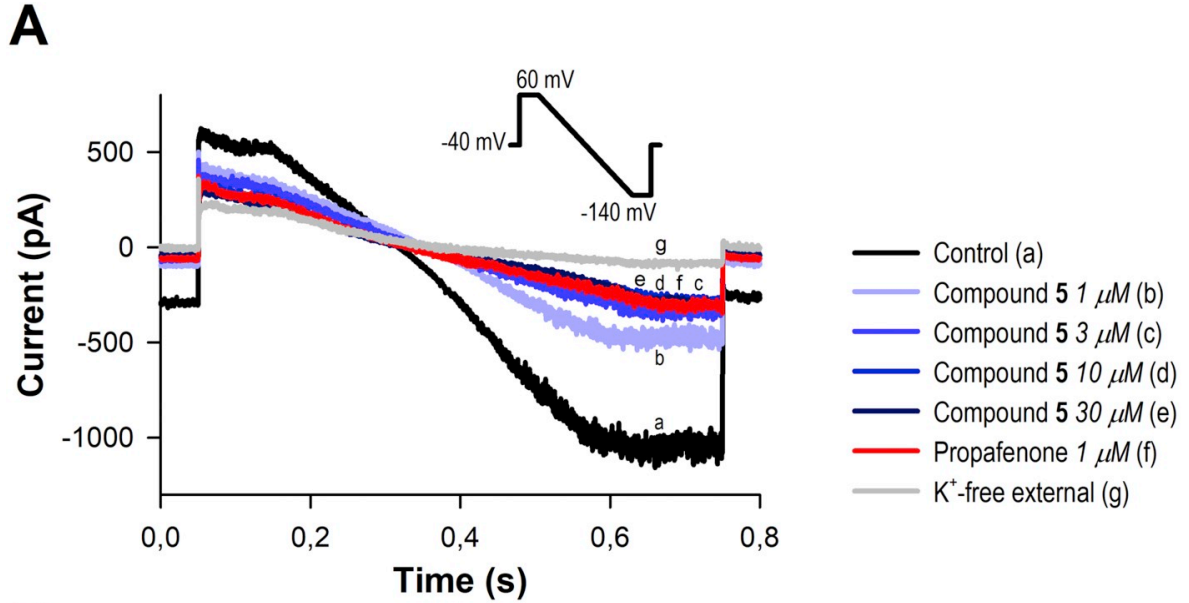

B

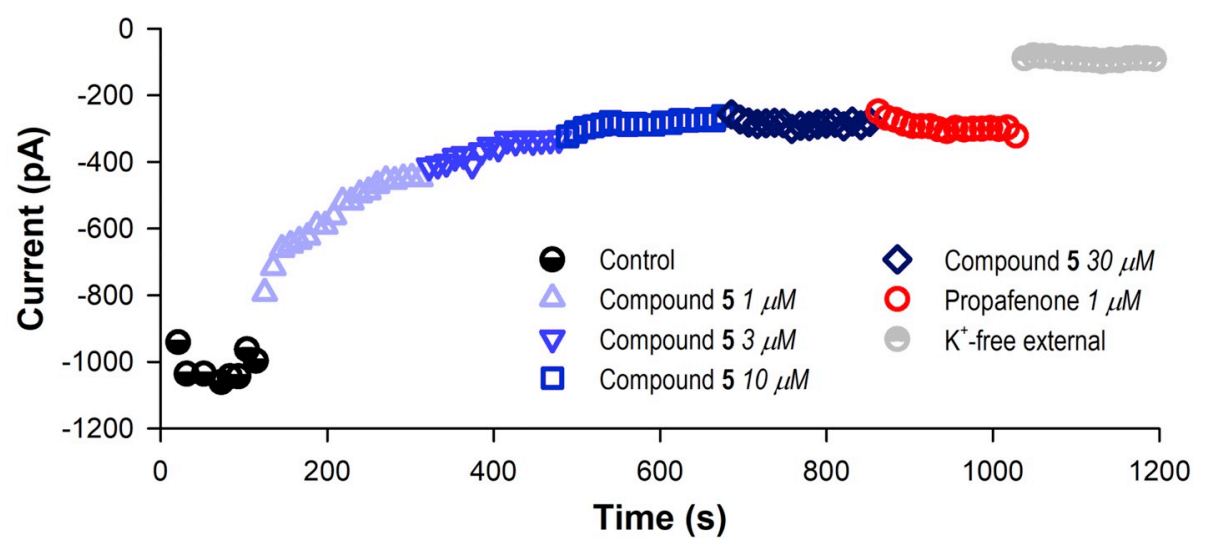

Fig. 3. Blocking effects of compound $\mathbf{5}$ on GIRK current. Panel A depicts original current sweeps which were recorded during application of compound 5 at $1 \mu \mathrm{M}, 3 \mu \mathrm{M}, 10 \mu \mathrm{M}$ and $30 \mu \mathrm{M}$ concentrations. Inset shows the applied GIRK voltage protocol. Time course of calculated inward currents from the $-140 \mathrm{mV}$ segment of the current curves is presented on panel B.
A, Figs. 1, 3 and 4) started with a depolarizing voltage step to $60 \mathrm{mV}$ for $100 \mathrm{~ms}$ before a $500 \mathrm{~ms}$ long hyperpolarizing ramp to $-140 \mathrm{mV}$ was applied. Then the membrane potential remained at $-140 \mathrm{mV}$ for $100 \mathrm{~ms}$ before returning to the holding potential of $-40 \mathrm{mV}$. The inward currents were calculated from the $-140 \mathrm{mV}$ segment. The pulse frequency was approximately $0.1 \mathrm{~Hz}$.

At the beginning of recordings, the normal external solution $\left(4 \mathrm{mM} \mathrm{K}^{+}\right)$was replaced to high $\mathrm{K}^{+}\left(25 \mathrm{mM} \mathrm{K}^{+}\right)$external solution in order to increase the current amplitude. After 2-3 min of control period, the test compounds were added to the cells in increasing concentrations, each for approximately $3 \mathrm{~min}$. Propafenone ( $1 \mu \mathrm{M}$, SigmaAldrich Corporation, St. Louis, USA) was used as a reference compound. In preliminary studies, we measured that the positive control propafenone exerted its effect with $373.0 \pm 27.7 \mathrm{nM} \mathrm{IC}_{50}$ value and at $1 \mu \mathrm{M}$ concentration inhibited the GIRK current by $71.4 \pm 4.6 \%(n=6)$. Finally, potassium free external solution was applied to completely cease inward potassium currents. The data were corrected with the current values measured in the potassium free external solution, which served as the baseline.

\subsection{2. hERG channel inhibitory assay}

hERG measurements were performed on HEK-293 cells stably transfected with cDNA encoding the hERG (Kv11.1) $\mathrm{K}^{+}$channel as described earlier in detail [21,22]. Cell line was purchased from Cell Culture Service (Hamburg, Germany). Cells were maintained in IMDM (PAN-Biotech GmbH, Aidenbach, Germany) medium supplemented with 10\% FBS (PAN-Biotech GmbH, Aidenbach, Germany), $2 \mathrm{mM} \mathrm{L}_{\mathrm{L}}$ glutamine (PAN-Biotech GmbH, Aidenbach, Germany), $1 \mathrm{mM}$ Na-pyruvate (PAN-Biotech GmbH, Aidenbach, Germany) and $500 \mu \mathrm{g} / \mathrm{mL}$ G418 (Thermo Fisher Scientific Inc., Waltham, USA).

The following solutions were used during patch-clamp experiments (compositions in $\mathrm{mM}$ ): external solution: $\mathrm{NaCl} 140, \mathrm{KCl} \mathrm{4}$, glucosemonohydrate 5, $\mathrm{MgCl}_{2} 1, \mathrm{CaCl}_{2} 3$ and HEPES 10 (pH 7.4, NaOH); internal solution: $\mathrm{KCl} 50, \mathrm{NaCl} 10, \mathrm{KF} 60$, EGTA 20 and HEPES 10 (pH 7.2, KOH).

The voltage protocol for hERG ion channel (see inset on Panel A, Fig. 5) started with a short $(100 \mathrm{~ms})-40 \mathrm{mV}$ step to establish the baseline region. A depolarizing step was applied to the test potential of $20 \mathrm{mV}$ for $3 \mathrm{~s}$, and then the cell was repolarized to $-40 \mathrm{mV}(1 \mathrm{~s})$ to evoke outward tail current. Holding potential was $-80 \mathrm{mV}$. The pulse frequency was approximately $0.1 \mathrm{~Hz}$. The peak tail current was corrected the leak current defined during the first period to $-40 \mathrm{mV}$.

Recording started in external solution. After this control period, the test compound was applied for approximately $3 \mathrm{~min}$. Following the test compound, $10 \mu \mathrm{M}$ amitriptyline was used as a reference inhibitor then a wash-out step terminated the pipetting protocol.

\subsection{Statistics}

All data are expressed as arithmetic means \pm standard error (SEM). Statistical analysis was performed with Student's $t$-test for paired data, and corrected using the Holm-Bonferroni method. Differences were considered statistically significant when $P$ value was $<0.05$.

\section{Results and discussion}

Initially, as part of the screening study the GIRK channel inhibitory effects of some mushroom extracts obtained from species native to Hungary were evaluated. Extracts were examined at two concentrations $(0.01 \mathrm{mg} / \mathrm{mL}$ and $0.1 \mathrm{mg} / \mathrm{mL})$ on two to three cells. Totally, 40 extracts of 10 higher basidiomycete mushrooms (see Table 1) were assessed: Gymnopus dryophilus, Laetiporus sulphureus, and Tricholoma populinum 
A

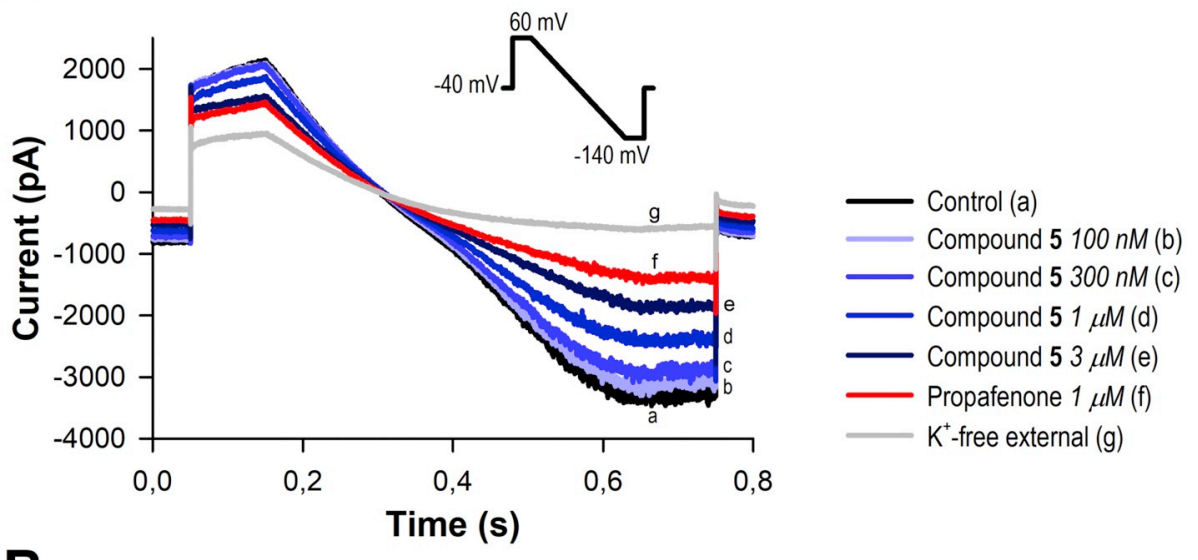

B

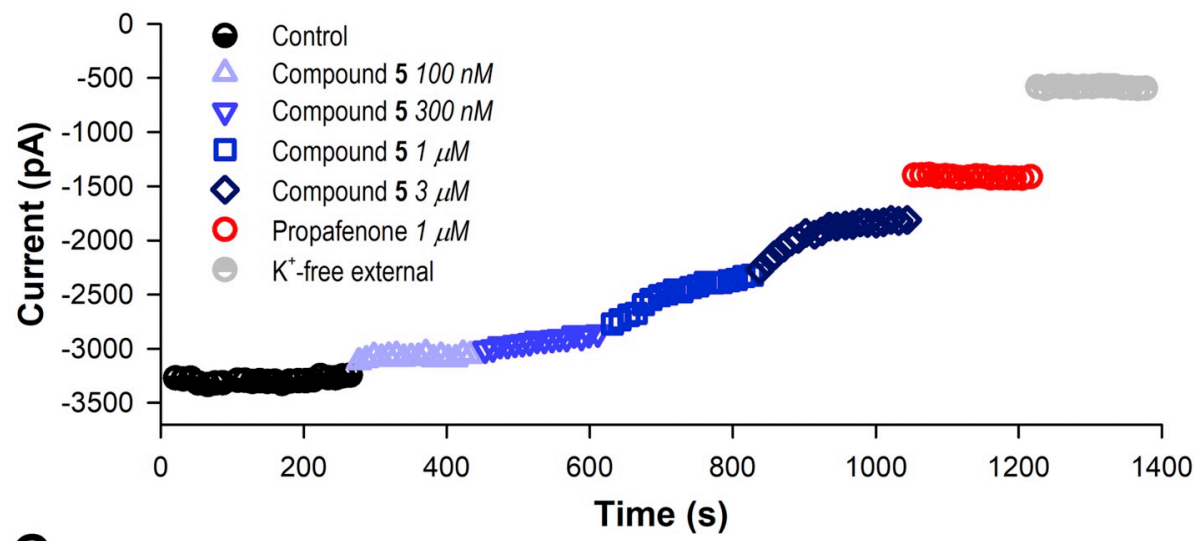

C

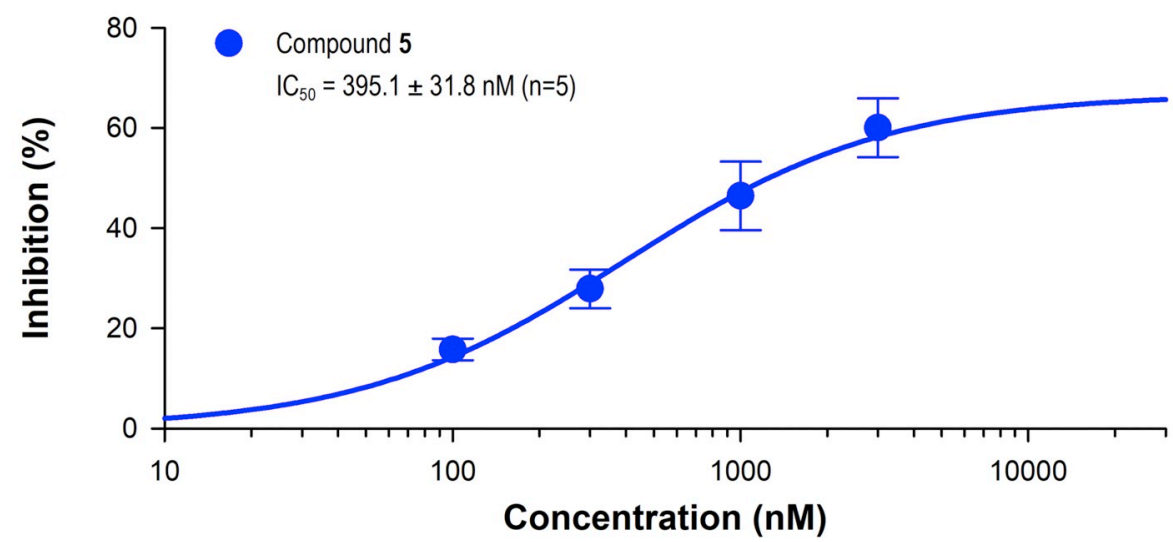

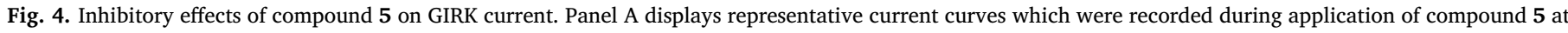

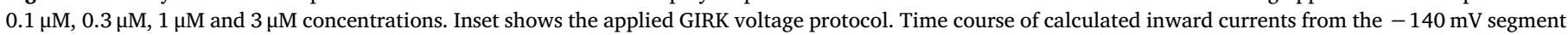

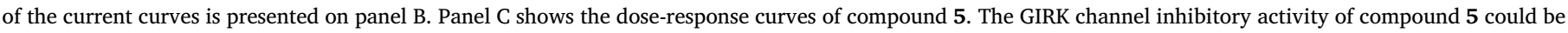
characterized by the relative $\mathrm{IC}_{50}$ value of $395.1 \pm 31.8 \mathrm{nM}(n=5)$.

are edible; Gymnopus fusipes, Hypholoma lateritium, Megacollybia platyphylla, Rhodocybe popinalis and Tricholomopsis rutilans are either not recommended for consumption or there are conflicting reports on their edibility; while Hebeloma sacchariolens and Hypholoma fasciculare are poisonous species. To the extent of our knowledge no other study has previously investigated the potential GIRK channel activity of mushrooms. According to the results obtained some fungal species display notable inhibitory activity on GIRK channel. G. dryophilus and G. fusipes are related mushrooms, which have not been extensively studied, the former contains a water-soluble polysaccharide, which has a potential immunomodulatory property based on the inhibition of NO production $[23,24]$; the latter is a parasitic, root-decay fungus, which has been recently identified as a source of unique cyclic octadecapeptides. [25]. Very little is known about the chemistry of $H$. sacchariolens, a small mushroom with a bitter taste, but a sweet and flowery smell. According to Wood et al., the source of the specific, pleasant odor is 2-aminobenzaldehyde [26]. H. lateritium, brick cap by its vernacular name, is a fairly popular edible mushroom in Japan, Korea and the United States, but in Europe it is considered inedible. Compared to its more common relative, the poisonous sulfur tuft ( $H$. fasciculare), the chemistry and 


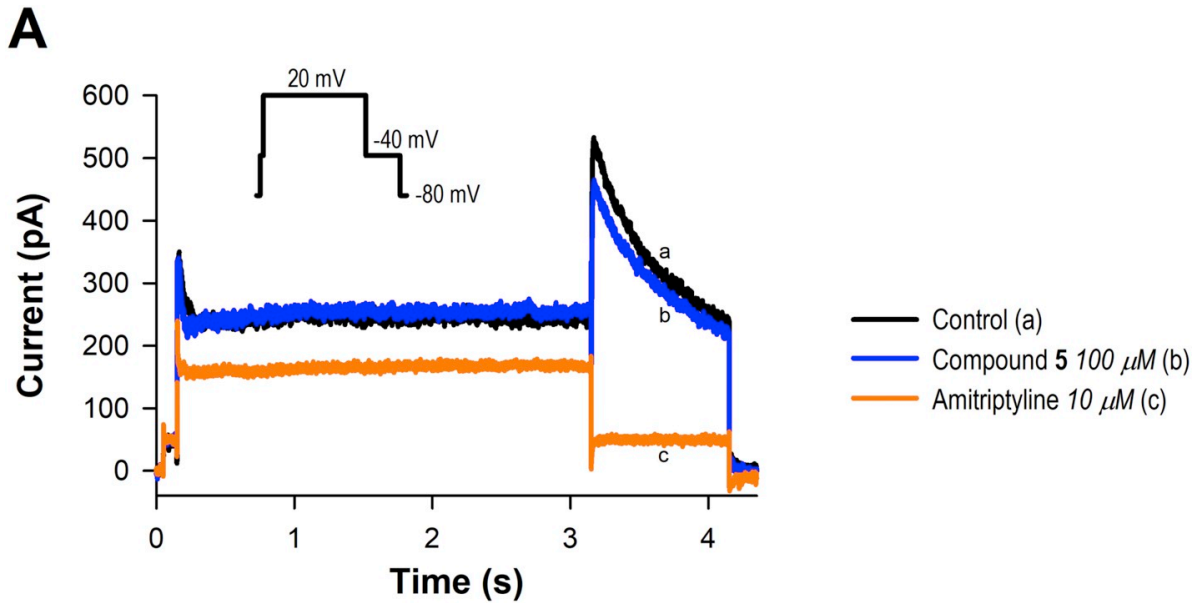

B

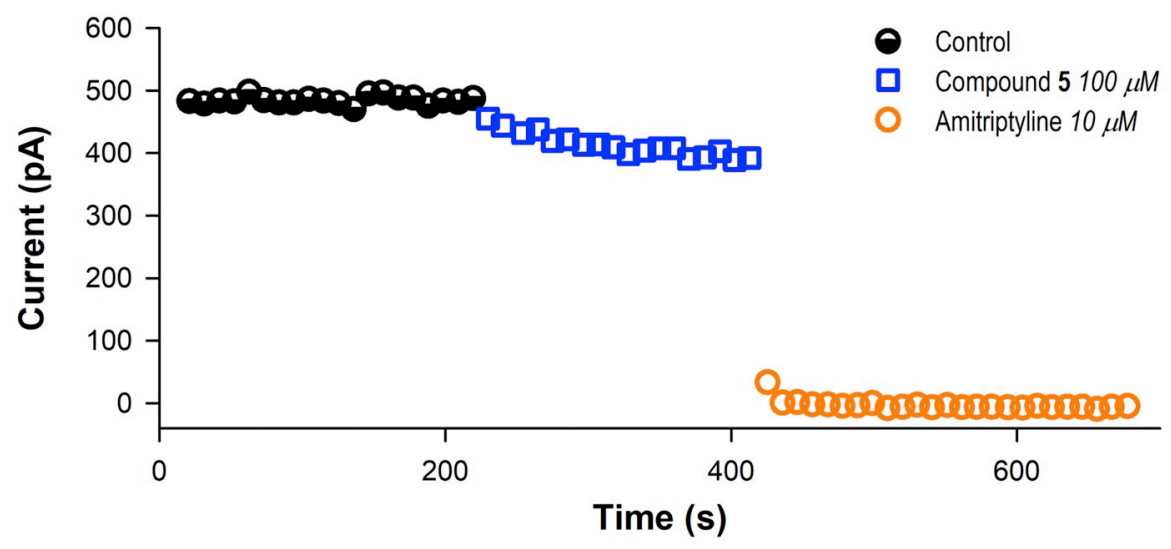

Fig. 5. Effects of compound 5 on hERG current. Panel A presents typical hERG current sweeps during the application of $100 \mu \mathrm{M}$ compound 5 . The inset shows the applied hERG voltage protocol. The original current traces reveal that $\mathbf{5}$ slightly blocked the hERG channel, while addition of reference compound amitriptyline $(10 \mu \mathrm{M})$ fully blocked the current. Time course of decrease in the peak tail current are presented on panel $\mathrm{B}$. pharmacology of $H$. lateritium are explored in a weaker extent. This species was found to produce several triterpenes e.g. fasciculols, fasciculic acids and sublateriols as well as sesquiterpenes eg. naematolin, a caryophyllane derivative with cytotoxic activity [27-29].

L. sulphureus, commonly known as sulphure polypore, is a delicious bracket fungus, growing on dead or living trees. It has a vast scientific literature, many of its chemical constituents (polysaccharides, triterpenes, polyene pigments) have been described [30-32], possessing a variety of pharmacological properties (anticancer, antimicrobial, antioxidant and hypoglycemic) [31,33,34]. T. populinum - also known as cottonwood mushroom - is a mycorrhizal fungus with lower culinary value which produces ergostane type steroids and methylsulfinyladenosine derivatives [35].

Among the fractions with different polarities, fraction A ( $n$-hexane fractions with the more lipophilic constituents) and fraction $\mathrm{B}\left(\mathrm{CHCl}_{3^{-}}\right.$ soluble compounds) proved to be active (i. e., at least $50 \%$ decrease in the current at $0.1 \mathrm{mg} / \mathrm{mL}$ concentration). The aqueous (fraction $\mathrm{D}$ ) and aqueous $\mathrm{MeOH}$ (fraction $\mathrm{C}$ ) extracts did not demonstrate considerable activity on GIRK channel ( $<40 \%$ decrease in the current at $0.1 \mathrm{mg} / \mathrm{mL}$ ) (see Table 2.)

However, there are some exceptions: neither fraction $\mathrm{B}$ of $R$. popinalis nor fraction $\mathrm{A}$ of $T$. populinum exerted remarkable blocking effect on the GIRK channel, whereas fractions C of L. sulphureus and H. lateritium proved to have notable inhibitory activities.

Fraction B of $H$. lateritium proved to be the most effective (53\% decrease on GIRK current) at the lower $(0.01 \mathrm{mg} / \mathrm{mL})$ concentration among the tested fungal extracts (Fig. 1).

Therefore, this species was chosen for in-depth chemical analysis in order to identify the secondary metabolites responsible for the observed ion channel activity. Thanks to combined chromatographic techniques we have previously identified a series of triterpenes (see Fig. 2): fasciculic acid B (1), fasciculol E (2), fasciculol C (3), fasciculol F (4), lanosta-7,9(11)-diene-12 $\beta, 21 \alpha$-epoxy-2 $\alpha, 3 \beta, 24 \beta, 25$-tetraol (5), demethylincisterol A2 (6), and 3ß-O-glucopyranosyl-5,8-epidioxyergosta6,22-diene (7), ergosterol (8), 3 $\beta$-hydroxyergosta-7,22-diene (9), and cerevisterol (10) [19].

The fungal metabolites were involved in the GIRK channel inhibitory assay at $1 \mu \mathrm{M}$ and $10 \mu \mathrm{M}$ concentrations. Compounds were tested on two to three cells (Table 3).

Most of the isolated metabolites possessed moderate activity on GIRK channel except compound 5, which found to be an active inhibitor of GIRK channel. Therefore, the dose-response curve and IC $_{50}$ value of $\mathbf{5}$ were characterized in detailed experiments where its effect was tested in 4 concentrations on 5 cells. Initially, investigations were performed at $1 \mu \mathrm{M}, 3 \mu \mathrm{M}, 10 \mu \mathrm{M}$ and $30 \mu \mathrm{M}$ concentrations. GIRK current was considerably reduced by these concentrations; the effects on the inward current were statistically significant in all tested concentrations. Application of compound 5 at $1 \mu \mathrm{M}$ concentration inhibited the GIRK current by $42.0 \pm 6.4 \%$. Elevation of the concentration of 5 to $3 \mu \mathrm{M}$ and to $10 \mu \mathrm{M}$ resulted in further decrease in GIRK current $(60.8 \pm 5.0 \%$ and $66.4 \pm 4.5 \%$ inhibitions, respectively). Further increase in test compound level did not alter the current $(66.7 \pm 4.6 \%$ inhibition at $30 \mu \mathrm{M})$. Consequently, the maximum effect was determined to this value, and, presumably, the drug may only inhibit $66.7 \%$ of the current even at the highest doses $\left(E_{\max }=0.6675\right)$. Original GIRK current curves and the time course of decrease in the current are shown on Fig. 3. Compound $\mathbf{5}$ was also tested in detailed experiments on GIRK cell line at $0.1 \mu \mathrm{M}, 0.3 \mu \mathrm{M}, 1 \mu \mathrm{M}$ and $3 \mu \mathrm{M}$ concentrations, in order to acquire the complete dose-response curve. GIRK current was considerably reduced by compound $\mathbf{5}$ in concentrationdependent manner. The relative $\mathrm{IC}_{50}$ value (the concentration corresponding to a response midway between the estimates of the lower and 
upper plateaus of the dose-response curve, i.e., $0 \%$ and $66.7 \%$ inhibition) was determined to be $395.1 \pm 31.8 \mathrm{nM}$ (Fig. 4) [36].

Compound 5 was also tested on HEK-hERG cell line and selectivity of their GIRK blocking effect was evaluated with these experiments. Selectivity study was performed at $100 \mu \mathrm{M}$ concentration on 12 cells. Compound 5 exhibited only slight inhibitory activity $(7.9 \pm 2.8 \%)$ on hERG channel even at this high concentration, showing more than three orders of magnitude higher blocking activity on GIRK channel compared to the results obtained on hERG channel. Original hERG current sweeps during the application of compound 5 at $100 \mu \mathrm{M}$ concentration and the time course of decrease in the peak tail current are shown on Fig. 5.

Atrial fibrillation (AF) is the most common serious abnormal heart rhythm. In the last two decades, AF has become a very important public health issue, and responsible for huge and rapidly growing healthcare expenditures in Western countries [1,37]. AF is present in $0.12 \%-0.16 \%$ of those younger than 49 years, in $3.7 \%-4.2 \%$ of those aged $60-70$ years, and in $10 \%-17 \%$ of those aged 80 years or older [37]. > 750,000 hospitalizations happen because of $\mathrm{AF}$, and it contributes to an estimated 130,000 deaths each year just in the U.S. [38]. Current antiarrhythmic drugs have numerous disadvantages, particularly the lack of atrial selectivity associated with an increased risk of side effects especially proarrhythmia and the poor efficacy rate (e.g., $50-60 \%$ for amiodarone, which is generally considered as the most effective drug). With this background, more targeted approaches are required to improve therapy of $\mathrm{AF}[1,39]$.

Exploiting the potential biological activity of macrofungi, extracts of basidiomycete mushrooms were investigated in our GIRK screen system, with the aim to identify natural sources of promising ion channel blocking compounds. Extracts of different polarity were screened, and one of the most active species, $H$. lateritium was further investigated for active compounds. Among fungal metabolites 1-10, compound $\mathbf{5}$ demonstrated notable blocking activity on GIRK current. Considering its intense blocking effect and high selectivity, $\mathbf{5}$ is a potential promising agent in treatment of $\mathrm{AF}$, despite no complete inhibition was observed. The current study unambiguously confirms that higher macrofungi deserve special attention in terms of secondary metabolites with valuable pharmacological properties.

\section{Declaration of Competing Interest}

The authors declare they have no conflict of interest.

\section{Acknowledgements}

Financial support from the Economic Development and Innovation Operative Program GINOP-2.3.2-15-2016-00012 is gratefully acknowledged. Grant 20391-3/2018/FEKUSTRAT awarded by the Ministry of Human Capacities, Hungary, is acknowledged. A. Ványolós is grateful for the grant of the Hungarian National Research, Development and Innovation Fund (PD 124476).

\section{References}

[1] N. Kúsz, P. Orvos, L. Bereczki, P. Fertey, P. Bombicz, A. Csorba, L. Tálosi, G. Jakab, J. Hohmann, D. Rédei, Diterpenoids from Euphorbia dulcis with potassium Ion channel inhibitory activity with selective $\mathrm{G}$ protein-activated inwardly rectifying ion channel (GIRK) blocking effect, J. Nat. Prod. 81 (2018) 2483-2492, https://doi. org/10.1021/acs.jnatprod.8b00500.

[2] D. Dobrev, A. Friedrich, N. Voigt, N. Jost, E. Wettwer, T. Christ, M. Knaut, U. Ravens, The G protein-gated potassium current I(K,ACh) is constitutively active in patients with chronic atrial fibrillation, Circulation. 112 (2005) 3697-3706, https://doi.org/10.1161/CIRCULATIONAHA.105.575332.

[3] G. Krapivinsky, E.A. Gordon, K. Wickman, B. Velimirović, L. Krapivinsky, D.E. Clapham, The G-protein-gated atrial $\mathrm{K}+$ channel IKACh is a heteromultimer of two inwardly rectifying $\mathrm{K}(+)$-channel proteins, Nature. 374 (1995) 135-141, https://doi.org/10.1038/374135a0.

[4] T.-J. Cha, J.R. Ehrlich, D. Chartier, X.-Y. Qi, L. Xiao, S. Nattel, Kir3-based inward rectifier potassium current: potential role in atrial tachycardia remodeling effects on atrial repolarization and arrhythmias, Circulation. 113 (2006) 1730-1737, https://doi.org/10.1161/CIRCULATIONAHA.105.561738.

[5] N. Voigt, A. Maguy, Y.-H. Yeh, X. Qi, U. Ravens, D. Dobrev, S. Nattel, Changes in I K ACh single-channel activity with atrial tachycardia remodelling in canine atrial cardiomyocytes, Cardiovasc. Res. 77 (2008) 35-43, https://doi.org/10.1093/cvr/ cvm051.

[6] N. Hashimoto, T. Yamashita, N. Tsuruzoe, Tertiapin, a selective IKACh blocker, terminates atrial fibrillation with selective atrial effective refractory period prolongation, Pharmacol. Res. 54 (2006) 136-141, https://doi.org/10.1016/j.phrs. 2006.03.021.

[7] N. Hashimoto, T. Yamashita, N. Tsuruzoe, Characterization of in vivo and in vitro electrophysiological and antiarrhythmic effects of a novel IKACh blocker, NIP-151: a comparison with an IKr-blocker dofetilide, J. Cardiovasc. Pharmacol. 51 (2008) 162-169, https://doi.org/10.1097/FJC.0b013e31815e854c.

[8] Y. Kubo, E. Reuveny, P.A. Slesinger, Y.N. Jan, L.Y. Jan, Primary structure and functional expression of a rat G-protein-coupled muscarinic potassium channel, Nature. 364 (1993) 802-806, https://doi.org/10.1038/364802a0.

[9] H. Dobrzynski, D.D. Marples, H. Musa, T.T. Yamanushi, Z. Henderson, Y. Takagishi, H. Honjo, I. Kodama, M.R. Boyett, Distribution of the muscarinic K + channel proteins Kir3.1 and Kir3.4 in the ventricle, atrium, and sinoatrial node of heart, J. Histochem. Cytochem. Off. J. Histochem. Soc. 49 (2001) 1221-1234, https://doi. org/10.1177/002215540104901004.

[10] C. Farre, S. Stoelzle, C. Haarmann, M. George, A. Brüggemann, N. Fertig, Automated ion channel screening: patch clamping made easy, Expert Opin. Ther. Targets 11 (2007) 557-565, https://doi.org/10.1517/14728222.11.4.557.

[11] M.C. Sanguinetti, C. Jiang, M.E. Curran, M.T. Keating, A mechanistic link between an inherited and an acquired cardiac arrhythmia: HERG encodes the $\mathrm{IKr}$ potassium channel, Cell. 81 (1995) 299-307, https://doi.org/10.1016/0092-8674(95) 90340-2.

[12] M.C. Trudeau, J.W. Warmke, B. Ganetzky, G.A. Robertson, HERG, a human inward rectifier in the voltage-gated potassium channel family, Science. 269 (1995) 92-95.

[13] J.C. Hancox, M.J. McPate, A. El Harchi, Y.H. Zhang, The hERG potassium channel and hERG screening for drug-induced torsades de pointes, Pharmacol. Ther. 119 (2008) 118-132, https://doi.org/10.1016/j.pharmthera.2008.05.009.

[14] C. Lengyel, A. Varró, K. Tábori, J.G. Papp, I. Baczkó, Combined pharmacological block of $\mathrm{I}(\mathrm{Kr})$ and $\mathrm{I}(\mathrm{Ks})$ increases short-term QT interval variability and provokes torsades de pointes, Br. J. Pharmacol. 151 (2007) 941-951, https://doi.org/10. 1038/sj.bjp.0707297.

[15] Y.G. Yap, A.J. Camm, Drug induced QT prolongation and torsades de pointes, Heart Br. Card. Soc. 89 (2003) 1363-1372, https://doi.org/10.1136/heart.89.11.1363.

[16] P. Orvos, Z. Kohajda, J. Szlovák, P. Gazdag, T. Árpádffy-Lovas, D. Tóth, A. Geramipour, L. Tálosi, N. Jost, A. Varró, L. Virág, Evaluation of possible proarrhythmic potency: comparison of the effect of dofetilide, cisapride, sotalol, terfenadine, and verapamil on hERG and native $\mathrm{IKr}$ currents and on cardiac action potential, Toxicol. Sci. Off. J. Soc. Toxicol. 168 (2019) 365-380, https://doi.org/10. 1093/toxsci/kfy299.

[17] M.J. Alves, I.C.F.R. Ferreira, J. Dias, V. Teixeira, A. Martins, M. Pintado, A review on antimicrobial activity of mushroom (Basidiomycetes) extracts and isolated compounds, Planta Med. 78 (2012) 1707-1718, https://doi.org/10.1055/s-00321315370.

[18] S.P. Wasser, Medicinal mushrooms as a source of antitumor and immunomodulating polysaccharides, Appl. Microbiol. Biotechnol. 60 (2002) 258-274 https://doi.org/10.1007/s00253-002-1076-7.

[19] B. Chuluunbaatar, Z. Béni, M. Dékány, B. Kovács, A. Sárközy, Z. Datki, L. Mácsai, J. Kálmán, J. Hohmann, A. Ványolós, Triterpenes from the mushroom hypholoma lateritium: isolation, structure determination and investigation in Bdelloid rotifer assays, Mol. Basel Switz. 24 (2019), https://doi.org/10.3390/molecules24020301.

[20] Nanion Technologies - Products - Patchliner, https://www.nanion.de/en/products/ patchliner.html, 2009, Accessed 19 December 2018

[21] A. Vasas, P. Forgo, P. Orvos, L. Tálosi, A. Csorba, G. Pinke, J. Hohmann, Myrsinane, premyrsinane, and cyclomyrsinane diterpenes from euphorbia falcata as potassium Ion channel inhibitors with selective $\mathrm{G}$ protein-activated inwardly rectifying ion channel (GIRK) blocking effects, J. Nat. Prod. 79 (2016) 1990-2004, https://doi. org/10.1021/acs.jnatprod.6b00260.

[22] P. Orvos, L. Virág, L. Tálosi, Z. Hajdú, D. Csupor, N. Jedlinszki, T. Szél, A. Varró, J. Hohmann, Effects of Chelidonium majus extracts and major alkaloids on hERG potassium channels and on dog cardiac action potential - a safety approach, Fitoterapia. 100 (2015) 156-165, https://doi.org/10.1016/j.fitote.2014.11.023.

[23] M. Pacheco-Sanchez, Y. Boutin, P. Angers, A. Gosselin, R.J. Tweddell, A bioactive (1- > 3)-, (1-4)-beta-D-glucan from Collybia dryophila and other mushrooms, Mycologia. 98 (2006) 180-185, https://doi.org/10.1080/15572536.2006. 11832690 .

[24] M. Pacheco-Sánchez, Y. Boutin, P. Angers, A. Gosselin, R.J. Tweddell, Inhibitory effect of CDP, a polysaccharide extracted from the mushroom Collybia dryophila, on nitric oxide synthase expression and nitric oxide production in macrophages, Eur. J. Pharmacol. 555 (2007) 61-66, https://doi.org/10.1016/j.ejphar.2006.10. 015.

[25] A. Ványolós, M. Dékány, B. Kovács, B. Krámos, P. Bérdi, I. Zupkó, J. Hohmann, Z. Béni, Gymnopeptides A and B, cyclic octadecapeptides from the mushroom gymnopus fusipes, Org. Lett. 18 (2016) 2688-2691, https://doi.org/10.1021/acs. orglett.6b01158.

[26] W.F. Wood, M. Brownson, R.A. Smudde, D.L. Largent, 2-Aminobenzaldehyde: the source of the "sweet odor" of Hebeloma sacchariolens, Mycologia. 84 (1992) 935-936, https://doi.org/10.2307/3760296.

[27] M. De Bernardi, G. Mellerio, G. Vidari, P. Vita-Finzi, G. Fronza, M. Kocòr, J. St. Pyrek, Fungal metabolites. IX. triterpenes from naematoloma sublateritium, J. Nat. 
Prod. 44 (1981) 351-356, https://doi.org/10.1021/np50015a020.

[28] Y. Yaoita, K. Matsuki, T. Iijima, S. Nakano, R. Kakuda, K. Machida, M. Kikuchi, New sterols and triterpenoids from four edible mushrooms, Chem. Pharm. Bull. (Tokyo). 49 (2001) 589-594, https://doi.org/10.1248/cpb.49.589.

[29] S. Backens, B. Steffan, W. Steglich, L. Zechlin, T. Anke, Antibiotika aus Basidiomyceten, XIX Naematolin und Naematolon, zwei Caryophyllan-Derivate aus Kulturen von Hypholoma-Arten (Agaricales), Liebigs Ann. Chem. 1984 (1984) 1332-1342, https://doi.org/10.1002/jlac.198419840709.

[30] G. Alquini, E.R. Carbonero, F.R. Rosado, C. Cosentino, M. Iacomini, Polysaccharides from the fruit bodies of the basidiomycete Laetiporus sulphureus (Bull.: Fr.) Murr, FEMS Microbiol. Lett. 230 (2004) 47-52, https://doi.org/10.1016/S0378-1097(03) 00853-X.

[31] F. León, J. Quintana, A. Rivera, F. Estévez, J. Bermejo, Lanostanoid triterpenes from Laetiporus sulphureus and apoptosis induction on HL-60 human myeloid leukemia cells, J. Nat. Prod. 67 (2004) 2008-2011, https://doi.org/10.1021/np049762o.

[32] P. Davoli, A. Mucci, L. Schenetti, R.W.S. Weber, Laetiporic acids, a family of noncarotenoid polyene pigments from fruit-bodies and liquid cultures of Laetiporus sulphureus (polyporales, fungi), Phytochemistry. 66 (2005) 817-823, https://doi. org/10.1016/j.phytochem.2005.01.023.

[33] A. Turkoglu, M.E. Duru, N. Mercan, I. Kivrak, K. Gezer, Antioxidant and antimicrobial activities of Laetiporus sulphureus (bull.) Murrill, Food Chem. 101 (2007)
267-273, https://doi.org/10.1016/j.foodchem.2006.01.025.

[34] H.S. Hwang, J.W. Yun, Hypoglycemic effect of polysaccharides produced by submerged mycelial culture of Laetiporus sulphureus on streptozotocininduced diabetic rats, Biotechnol. Bioprocess Eng. 15 (2010) 173-181, https://doi.org/10. 1007/s12257-009-0160-6.

[35] B. Kovács, Z. Béni, M. Dékány, O. Orbán-Gyapai, I. Sinka, I. Zupkó, J. Hohmann, A. Ványolós, Chemical analysis of the edible mushroom Tricholoma populinum: steroids and sulfinyladenosine compounds, Nat. Prod. Commun. 12 (2017) 1583-1584.

[36] J.L. Sebaugh, Guidelines for accurate EC50/IC50 estimation, Pharm. Stat. 10 (2011) 128-134, https://doi.org/10.1002/pst.426.

[37] M. Zoni-Berisso, F. Lercari, T. Carazza, S. Domenicucci, Epidemiology of atrial fibrillation: European perspective, Clin. Epidemiol. 6 (2014) 213-220, https://doi. org $/ 10.2147 /$ CLEP.S47385.

[38] Atrial Fibrillation Fact Sheet|Data \& Statistics|DHDSP|CDC, https://www.cdc.gov/ dhdsp/data_statistics/fact_sheets/fs_atrial_fibrillation.htm, (2018) , Accessed date: 23 January 2019.

[39] C.E. Woods, J. Olgin, Atrial fibrillation therapy now and in the future: drugs, biologicals, and ablation, Circ. Res. 114 (2014) 1532-1546, https://doi.org/10.1161/ CIRCRESAHA.114.302362. 